\title{
APPLICATION OF COMPOSITE WOODEN BEAMS IN THE RENOVATION OF HIGH ROOFS
}

\author{
Mátyás Ress ${ }^{1}$ \\ Annamária Dudás ${ }^{2}$ \\ Valéria V. Horn ${ }^{3}$
}

UDK: 692.4:624.072.2

DOI: $10.14415 /$ konferencijaGFS2018.006

Summary: Until the past decades only sawn timber beams has been used in the construction of buildings with high-roof. By increasing the price of quality wood and by optimizing the use of lumber, the growing number of glued laminated timber beams are produced. To increase the bearing capacity, I-shape cross-sectional structures are used, in which the web and flange are made of other wood-based boards. Following the aspects of sustainable development, the increase in recycling in the construction industry is a priority objective in an indirect or direct way, so in the research building with the used wooden elements, e.g. formwork beams also were investigated. In the roof structure reconstruction of the family houses with wooden slabs the composite beam structures provide a good solution due to their low weight and high load-bearing capacity. The article deals with the summing and analysis of these solutions.

Keywords: high-roof, reconstruction, composite wooden beam, reuse

\section{INTRODUCTION}

One of the key features of environmentally conscious construction is the reuse of the building materials and in certain cases building structures also. This approach has an increasing effect in design. With the repeated inbuilt of building materials from demolished buildings the life cycle of the material is considerably increased, substituting a significant amount of new building material. There is more ambition to create an environmental load performance certificate similar to the one for energy performance of new buildings. Recycling of materials and structures plays a substantial role in such rating. At the same time, little attention has been paid to the recycling of elements of construction aids, e.g. formworks and scaffoldings.

Formwork systems and its supporting structures are considered to be waste after many times use, although in some other form they could be recycled. The article represents the

\footnotetext{
${ }^{1}$ Mátyás Ress, MSc civil eng., H-1116 Budapest, Hunyadi J. street 162. Hungary, tel: +36 2056756 56, e-mail: ressmatyas@gmail.com

2 Annamária Dudás, PhD. civil eng., associate professor of Budapest University of Technology and Economics, Faculty of Civil Engineering, Department of Construction Materials and Technologies, H-1111 Budapest, Hungary, tel: +36146323 73, e-mail: dudas.annamaria@epito.bme.hu

${ }^{3}$ Valéria V. Horn, DLA, architect, assistant professor of Budapest University of Technology and Economics, Faculty of Civil Engineering, Department of Construction Materials and Technologies, H-1111 Budapest, Hungary, tel: +36146323 73, e - mail: horn.valeria@epito.bme.hu
} 
Савремена достигнућа у грађевинарству 20. април 2018. Суботица, СРБИЈА

analyzing of different solutions for further use of formwork beams. At the same time, the multipurpose reuse of formwork beams is also ensured by the fact that rebuilding of beams is possible not only in the horizontal plane, but also in the oblique and vertical positions. The presented structural details have been developed for the Doka laminatedglued elements in the MSc Thesis work in civil engineering of Ress, M. [1].

\section{APPLICATION OF WOODEN I-SHAPE COMPOSITE BEAMS}

In the construction practice, the appearance of wood-based composite elements was initiated by the economical use of wood and the minimization of wood-based waste generated in the sawmills. It can be emphasized as an advantage from structural point of view that the I-shape cross section can provide the same load-bearing capacity with lower material application than the rectangular cross-section of lumbers. Moreover, the different raw material of the web and the flanges provides additional economical solutions. The web of the composite beams could be laminated, oriented strand board (OSB) or even as a glued wooden particle plate, while the flanges are made from lumber or laminated glued beams.

Composite beams are often used as supporting beams for slabs and are also used as frame elements for timber-framed residential buildings (manufacturers e.g. Steico [2], Finnjoist-Metsä Wood [3], Oakworth Timber Engineering [4], Boise Cascade [5], Georgia -Pacific [6], LP Solid Start I-Joist [7], etc.) (Fig. 1., 2.). Another special variant is I-cross beam with a geometry similar to the above mentioned ones, but the web is made of steel trapezoidal sheet, thus combining the beneficial properties of different materials (e.g. NailWeb [8]).

The I-shape composite beams are most frequently used as elements of formwork systems (Fig. 3., 4.) (manufacturers e.g. Doka [9], Peri [10], Meva [11], Ulma [12], Preifer [13], etc.).

Most of the manufacturers and distributors of wood-based composite beams are in the group of Wood I-Joist Manufacturers Association (WIJMA) [14].

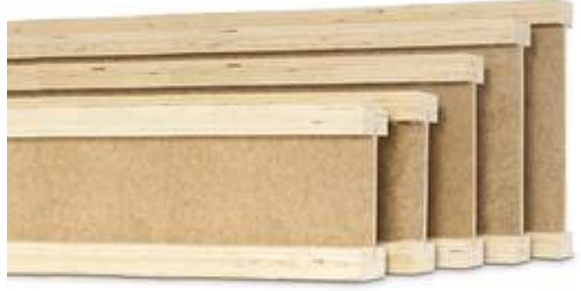

Figure 1. I-Joists with solid timber flange and wooden fibre web [2]

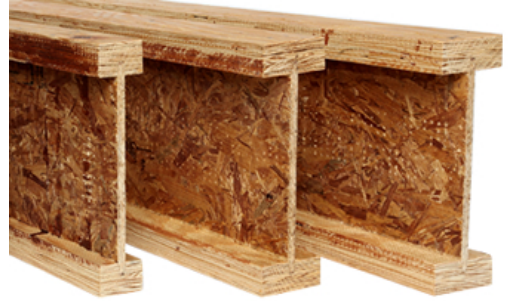

Figure 2. I-Joists with laminated veneer lumber flanges and OSB web [6]

The cross-sectional form I is favorable from building physical aspects, since the narrow web of the elements significantly reduces the effect of thermal-bridge through the axis of the structures built-in as wall studs or roof rafters.

Several scientific articles deal with composite structures and their load-bearing capacity from structural point of view. M. Shahidul Islam and his co-authors investigated 
Contemporary achievements in civil engineering 20. April 2018. Subotica, SERBIA

defectively formed cuts made during the construction of structures with wooden flange and OSB web composite beams, for various geometrical shortages [15]. Their experimental tests were carried out in 100 variants and it was concluded that the size and position of the shortage in the beam along the length of the support also influences the reduced capacity. E.C. Zhu et al. investigated the effects of holes of the web plate of composite beams for pipe penetrations by experiments and structural simulations. The article describes the finite element modeling of composite beams with OSB web for circular and square shape holes [16].

P. Racher and his co-authors examined the geometry of composite I-joists, specifically in relation to their height, in comparison of their load capacity. In their article [17] it was represented that the finite element simulations and experimental measurements were also carried out, exaggerating the connection of the head of the web into the flange. J.J. del Coz Díaz et al. also analyzed composite elements in their articles by finite element method and on experimental basis [18]. A. Lokaja, K. Klajmonová authors presented a study based on their experiments about the load bearing capacity of I-joists with solid wood flange and OSB web as well [19].

\section{ELEMENTS OF FORMWORK SYSTEMS}

During the building process of reinforced concrete structures, only formwork systems are used nowadays. There is a significant difference between the horizontal and the vertical solutions. The formwork boards can typically be made of wood, plywood, composite, plastic or metal. The posts consist of metal tubular elements for which the loads are transmitted by the formwork beams. The statical behaviour of the inbuilt Ijoists beams is single supported beam, where the free supports are realized by U-heads.

The properties of the beams typically differ in geometry and in the material of the webs and flanges per manufacturer. Flanges of wooden I-joists are generaly made of sawn timber, while their web may be laminated glued, OSB or wooden particle board as well (Fig. 3., 4.).

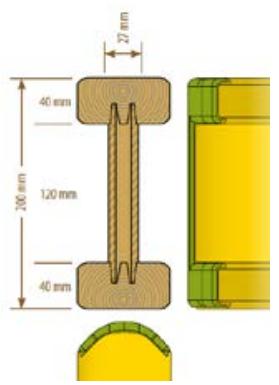

Figure 3. Pfeifer formwork beam [13]

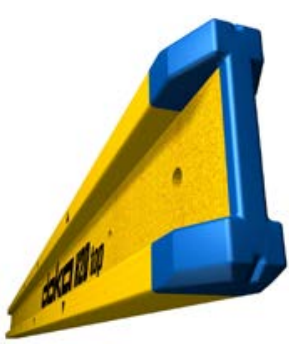

Figure 4. Doka formwork beam [9]

There is a significant difference between the load-bearing capacity belongs to each web formations. I-joists with laminated glued webs has the best load-bearing capacity, but the I-joists with wooden particle webs are cheaper. Table 1 . summarizes the main features of the $20 \mathrm{~cm}$ height formwork beams for different manufacturers. 
Table 1. Main features of formwork beams [1,9,10,12,13]

\begin{tabular}{|l|c|c|c|c|}
\hline \multirow{2}{*}{ Feature } & \multicolumn{4}{|c|}{ Manufacturer and type } \\
\cline { 2 - 5 } & $\begin{array}{c}\text { DOKA } \\
\text { Top 20 }\end{array}$ & $\begin{array}{c}\text { Peri } \\
\text { VT20K }\end{array}$ & $\begin{array}{c}\text { ULMa } \\
\text { VM20 }\end{array}$ & $\begin{array}{c}\text { Preifer } \\
\text { PF20 }\end{array}$ \\
\hline Height [cm] & 20 & 20 & 20 & 20 \\
\hline Web & solid & solid & solid & solid \\
\hline Length [m] & $1,80-5,90$ & $1,45-5,90$ & $1,45-5,90$ & $2,45-5,90$ \\
\hline Weight [kg/fm] & 5,60 & 5,90 & 4,60 & 4,50 \\
\hline Permitted load at supports [kN] & 20 & 22 & 23,9 & 23,9 \\
\hline $\begin{array}{l}\text { Permitted bending moment } \\
{[\mathrm{kNm}]}\end{array}$ & 9 & 5 & 10,9 & 10,9 \\
\hline $\begin{array}{l}\text { Rigidity / Flexural strength } \\
{\left[\mathrm{kNm}^{2}\right]}\end{array}$ & 640 & 460 & 461,3 & 450 \\
\hline Inercia [cm $\left.{ }^{4}\right]$ & n.i. & 4,181 & 4,613 & n.i. \\
\hline
\end{tabular}

\section{Criteria for reuse of formwork elements [1, 9]}

The conformity of the repeated installation of the formwork elements is verified in two ways based on manufacturer recommendations. First, they make a visual inspection, next they examine the modulus of elasticity (Young's modulus). The values given by the manufacturer are valid for a maximum relative humidity of $20 \%$, in other cases the limit values are to be adjusted depending on the water content. The use of beams is prohibited if the damages are beyond the following limits. Requirements regarding the state of a beam:

- $\quad$ Angled cracks across the grain are not permissible.

- $\quad$ Maximum $2 \mathrm{~mm}$ width cracks are permissible parallel to the flange. "If the flange can be parted at the crack the beam is not in usable condition. “ [9]

- $\quad$ Splintering at the total width of the flange is permissible just up to $10 \mathrm{~mm}$ depth and $500 \mathrm{~mm}$ width, but just in one flange.

- $\quad$ Angled splintering across the edge is permissible just up to $30 \mathrm{~mm}$ width across the diagonal and length $500 \mathrm{~mm}$.

- $\quad$ Saw cuts perpendicular to the flange deeper than $2 \mathrm{~mm}$ are not permissible.

- Splintering damage at the end of the flange must not be longer than $60 \mathrm{~mm}$.

- $\quad$ There are detailed rules of the manufacturer belongs to drilled holes: what is the maximum diameter for the holes and where these could be on the beam. [see 9]

- In the web of the beam just those damages are permissible which do not pierce the structural thickness of the web.

- $\quad$ The maximum damage of the web end is $20 \mathrm{~mm}$.

- $\quad$ "One drilled hole of maximum diameter $20 \mathrm{~mm}$ per running meter in addition to the system holes is permissible.“

- $\quad$ "Detachment of flange from web is not permissible." [9]

Decluttering is often required due to damage of the end of the I-joints. However, at the time of reusing the beams, regarding the dimensioning, the damaged parts could be removed. Thus, elements considered waste as part of the formwork system can be fully reused as other structural elements. 
Contemporary achievements in civil engineering 20. April 2018. Subotica, SERBIA

\section{ROOF RECONSTRUCTION}

\subsection{Engineered roof system}

In Hungary, the majority of detached houses and terraced houses have high roof. In the case of family houses built after World War II, the sawn timber was often not of good quality. In addition, there is a lack of underlayer foil insulation under the roof cladding, which is why the roof structures have suffered significant damage and need to be refurbished.

Many examples of folk architecture - residential buildings and outbuildings - were made with narrow building widths. In these buildings a wooden slab and an empty high roof were built. Due to their state they need to be significantly refurbished. Because of the leakage of claddings and of the significant insect and mildew damage, furthermore of the inadequate material quality, wood replacement is often inevitable. It is therefore advisable to add a new roof structure. If the roof is connected to the slab and it is also damaged, rebuilding of the slab is also required.

The length of the recycled Doka beams of 1.80-5.90 m makes it possible to built them in at the reconstruction of roofs with a smaller span. Furthermore, with necessarily reinforced solutions, the originally unused attics can be utilized with these application.

Because of the Doka beams are made of sawn timber flange and laminated glued web, the spatial connections of the beams can be made with steel plate straps, hinges, fixing elements and screw connections. The presented examples were designed for the reconstruction of a residential building in the [1] MSc thesis of M. Ress, who detailed and designed the various load-bearing structural solutions of reused formwork beams. Within the framework of this article only a few structural detail can be presented.

Figure 5. shows structural solutions of ridge details with formwork beams. In the lefthand version, the joining of the rafters and the fixing of the ridge purlin between the rafters is solved with steel connectors. The shear force is transmitted through the web with a $61 \%$ utilization. In the right-hand version of Figure 5., there is no steel connecting element, the flanges are cut off on one side of the rafters into the web's plane.
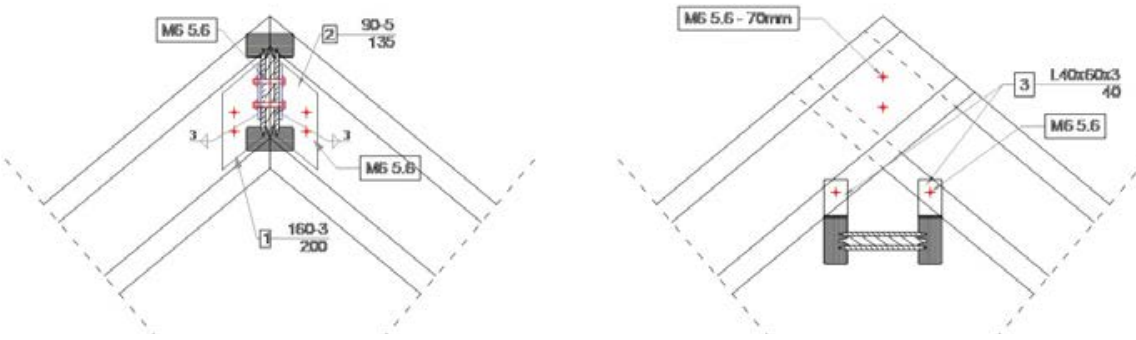

Figure 5. Two versions for structural solutions of ridge

This resulted a single sheared wooden connection, and the two through-bolt were utilized with $83 \%$. The longitudinal axes of the two rafters are not in one plane, so the supporting may cause difficulty at the base purlins. 
Савремена достигнућа у грађевинарству 20. април 2018. Суботица, СРБИЈА

One of the variants of fixing the rafter beams to the base purlin is shown in Figure 6. In this case, it is a new roof structure supported by a base purlin on the extant wooden slab. Prior to the realization, an expert in wooden materials must examine the condition of the slab. This version has a solution in which formwork beams are attached to existing structures with an adjustable inclination fastening element.

This fastener is advantageous in that it can be manufactured as prefabricated element without the knowledge of the roof angle. In the connection the normal force utilization is $83 \%$ and the shear force utilization is $65 \%$. In the web, a hole corresponding to twice the diameter of the stud must be drilled, so the stud seats not on the wood but on the steel plate.
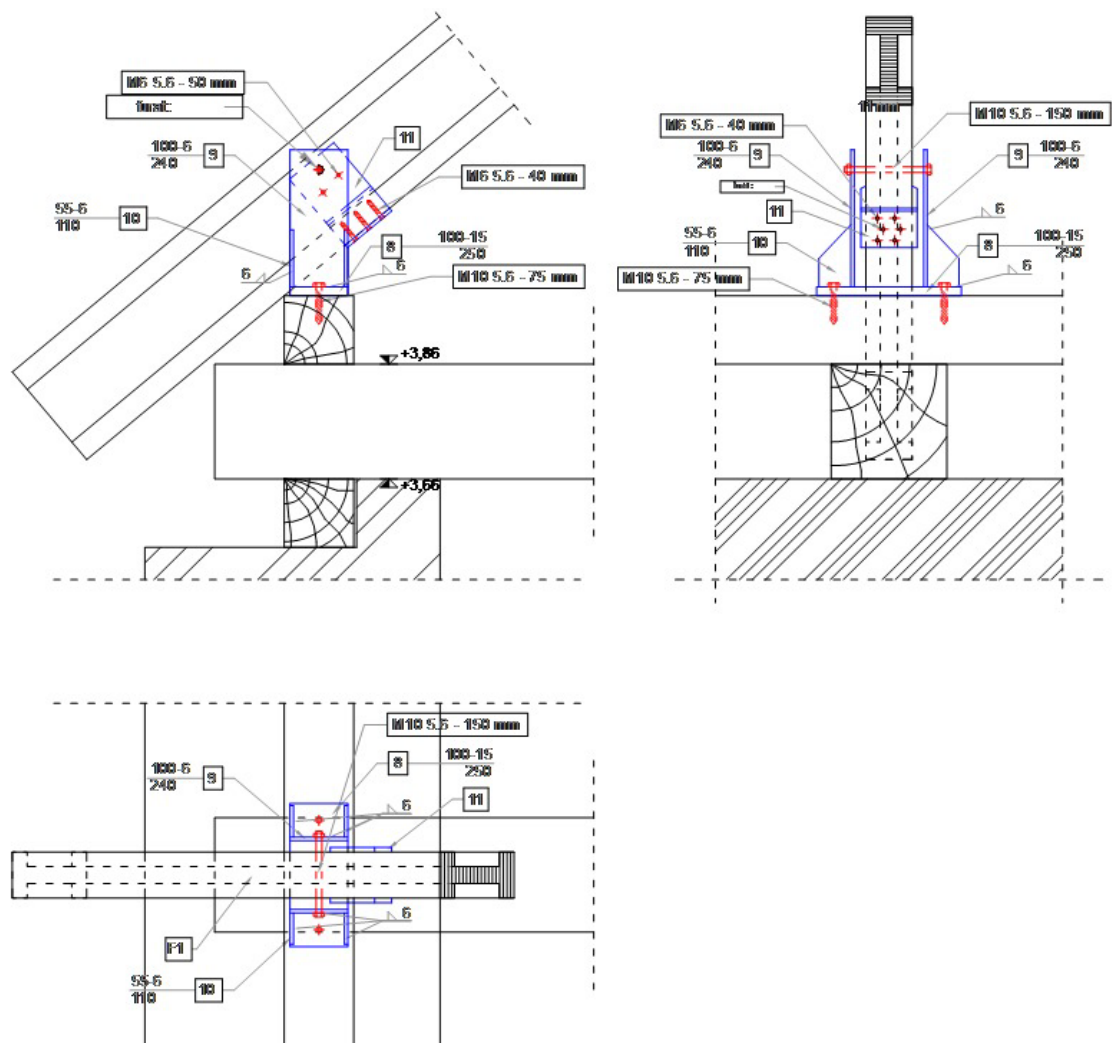

Figure 6. Anchorage of rafter beams with fastening element to the extant slab

New slab beams and rafters are connected in Figure 7., where traditional overhanging of the eave is formed. The load transfer is effected only by means of screws through the beams. A metal connecting element is required for fastening the slab beams to the supporting base purlin, which takes on the considerable torsion from the eccentricity. For torsion stress the utilization rate is $85 \%$, the screw is tensile loaded. 
Contemporary achievements in civil engineering 20. April 2018. Subotica, SERBIA

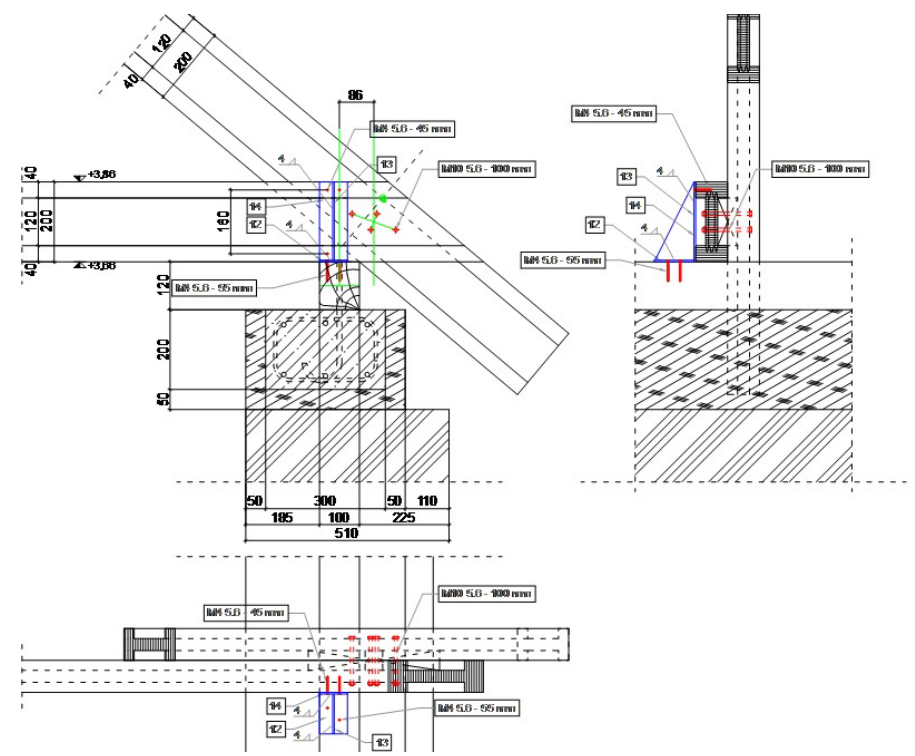

Figure 7. Detail of the connection of rafter and new slab beam with a cutwork insert

The connection of new slab and rafters can also be achieved without an overhang with the inclined cut of the beams (Fig. 8.), the rafter sit on the top of the slab beam. Then the normal force (83.5 \% utilization) is taken by the flanges, the shear force (90\% utilization) is taken by the web. Although it is a central connection, the detail is fixed to the base purlin as the connection would be with eccentricity.

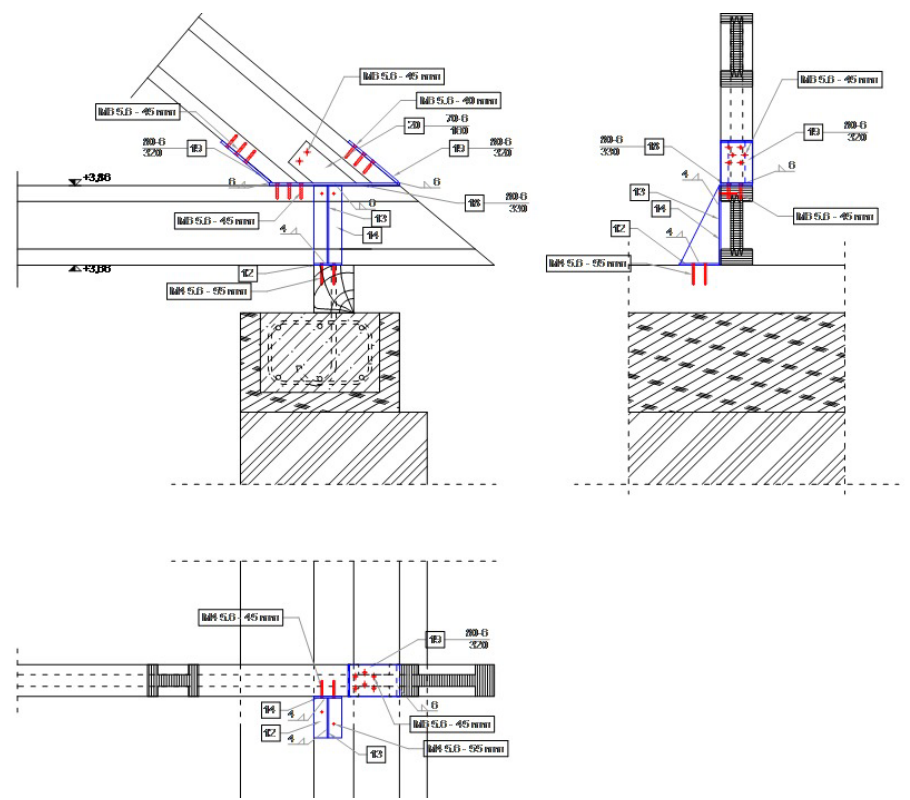

Figure 8. Connection of slab and rafter beams in the same plane with steel element 
Савремена достигнућа у грађевинарству 20. април 2018. Суботица, СРБИЈА

As it can be seen from the previous figures, it would be quick and easy to construct precise and economical engineered roof structures with steel connecting elements.

Moreover, recycling of formwork beams not only roofs comparable to conventional roofing structures could be built. In the case of larger building spans, the beams can be formed into spatial rod system by inserting hinged steel joints. Due to the variable inclination of the roof, it is advisable to use this construction primarily for agricultural and storage buildings.

\section{REUSE OF FORMWORK BEAMS FOR SECONDARY SUPPORTING STRUCTURES}

\subsection{Posterior thermal insulation of building facades}

The exterior insulation of existing residential buildings remains up to date for many years. For insulation of one or two-storey residential buildings, the following possibilities are available for the recycling of formwork beams: the beams are fixed in front of the facade with the exclusion of the designed window and door openings. On the outer surface of the beams a building board made from renewable sources is installed and thermal insulation is inserted between the beams. This can be cellulose (recycled paper) or other environmentally friendly thermal insulation. A thermal vapour permeable, airtight foil is required between the insulation and the building board. The exteriorly insulated facade can also be built with a ventilation air gap. Any cladding can be formed in front of a wooden lath skeleton. (Fig. 9.) In this case, the free flow of air can be ensured between counter battens. This is a favourable construction regarding vapour diffusion, thermal insulation and shading. For a construction without ventilation gap plasterable construction board, e.g. cement-based wood wool (Heraklith [20]) is required. Due to the small dead-load of the frame, these structures minimize the loading of the existing structures. The structure is easily demountable and can be converted.

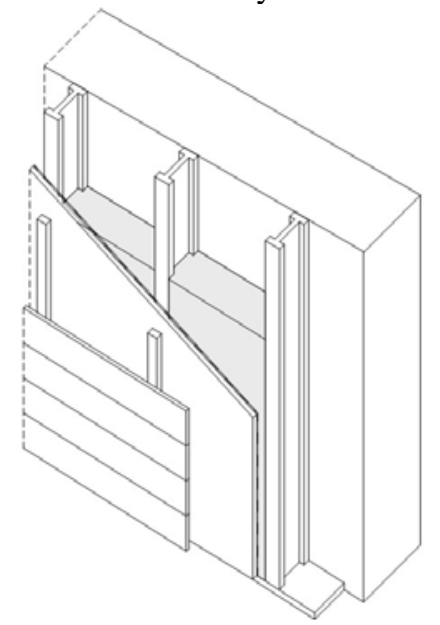

Figure 9. Reused formwork beams as secondary supporting structures at the facades 
Contemporary achievements in civil engineering 20. April 2018. Subotica, SERBIA

\subsection{Wall-panel sceleton built from reused formwork beams}

Recycled beams can be used to create room-size wall panels with appropriate dooropening exclusion (Fig. 10.). This can further expand the constructions of wood and thin-walled steel lightweight construction of residential buildings.

The vertical studs of the wall panel are framed by planks at the bottom and on the top. Spatial connections - after design calculations - can be solved with hot-dip galvanized steel elements (e.g. Simpson Strong-Tie [21]). In the case of wall panels, the beams with a length of $2.65 \mathrm{~m}$ to $2.90 \mathrm{~m}$ are particularly useful. A solid plank frame is required at the openings, where the planks give the substructure of the fix frame of the door. It also solves the structure of the lintel above the opening. If it is necessary for the parapet, and from the lintel level to the top of the panel, cut formwork studs could be installed. The buckling of the studs is prevented by the outer and inner building boards (e.g. fibreboard). With the wall panel you can solve both the external and the internal loadbearing walls. Interior partition walls are provided with plasterboard systems.

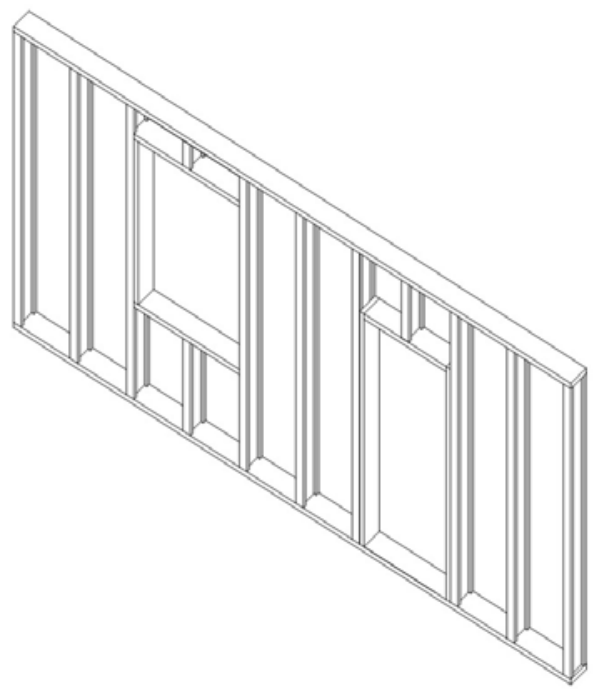

Figure 10. Wall-panel sceleton from reused formwork beams with openings

\section{CONCLUSION}

Primary energy consumption of the new constructions would be reduced with the presented recycling of formwork beams. The structures built with these form of beams are energy efficient. The I-joists are made of a variety of wood. Sawn timber flanges needs lower production energy than the plywood web, moreover cutting off the plates from the $\log$ and the glue production requires energy too. A beam can travel for hundreds of kilometers throughout its lifetime, and taking this into account also affects how much it can be considered environmentally friendly. If the formwork beams were destroyed, in addition to the carbon dioxide released from wood, the glue and paint would become highly toxic gases, the neutralization of which would be resource- 
6.

МЕЂУНАРОДНА КОНФЕРЕНЦИЈА

Савремена достигнућа у грађевинарству 20. април 2018. Суботица, СРБИЈА

demanding. By contrast during the rebuilding of the formwork elements do not require wood protection and surface treatment. In conclusion it can be stated that the reusing of formwork beams is an environmentally friendly solution.

\section{REFERENCES}

[1] Ress, M.: Mérnöki fedélszék-rendszer tervezése újrahasznosított zsalugerendából (Design of engineered roof system from recycled formwork beams), MSc Thesis, manuscript, 2017.

[2] http://www.steico.com/en/

[3] https://www.metsawood.com/uk/Products/Finnjoist-i-beam/Pages/Finnjoist-ibeam.aspx

[4] http://www.oakworthtimberengineering.co.uk/I-joist-I-beam.html

[5] https://www.bc.com/manufacturing/?ctp=ew

[6] https://www.buildgp.com/Engineered-Lumber

[7] https://pcorp.com/products/framing/i-joists/

[8] http://www.nailweb.fr/

[9] https://www.doka.com

[10] https://www.peri.com/en

[11] http://www.mevaformwork.co.uk/en/index.php

[12] https://www.ulmaconstruction.com/en/formwork

[13] https://www.pfeifergroup.com/en/products/formwork-products/formworkbeams/the-product/

[14] Wood I-Joist Manufacturers Association (WIJMA) http://i-joist.org/

[15] M. Shahidul Islam, Md. Shahnewaz, M. Shahria Alam: Structural capacity of timber I-joist with flange notch: Experimental evaluation, Construction and Building Materials 2015., vol. 79, p.p. 290-300.

[16] E.C. Zhu, Z.W. Guan*, P.D. Rodd, D.J. Pope: Finite element modelling of OSB webbed timber I-beams with interactions between openings, Advances in Engineering Software, 2005., vol. 36, p.p. 797-80.

[17] Racher, P., Bocquet, J.F. Bouchair, A.: Effect of web stiffness on the bending behaviour of timber composite I-beams, Materials and Design, 2007., vol. 28, p.p. 844-849.

[18] del Coz Díaz, J.J., García Nieto, P.J., Lozano Martínez-Luengas, A., Suarez Domínguez, F.J., Domínguez Hernández, J.: Non-linear numerical analysis of plywood board timber connections by DOE-FEM and full-scale experimental validation, Engineering Structures, 2013., vol. 49, p.p. 76-90.

[19] Lokaja, A., Klajmonová, K.: Problems of wood-based I-beams carrying capacity, Procedia Engineering, 2017., vol. 190, p.p. 271 - 274.

[20] http://heraklith.co.uk/

[21] https://www.strongtie.com/

All the downloading of refered websites were between 10-17.03.2018. 